\title{
29. DINOCYSTS IN TERTIARY NORWEGIAN-GREENLAND SEA SEDIMENTS (DEEP SEA DRILLING PROJECT LEG 38), WITH OBSERVATIONS ON PALYNOMORPHS AND PALYNODEBRIS IN RELATION TO ENVIRONMENT
}

\author{
Svein B. Manum, Institutt for geologi, Universitetet i Oslo, Postboks 1047, Blindern, Oslo 3, Norway
}

\begin{abstract}
Eocene to Miocene sediments from 15 holes drilled in the Norwegian-Greenland Sea contain dinoflagellate cysts in varying amounts and usually of good preservation. Stratigraphic ranges for 85 cyst morphotypes (not described) form the basis for a provisional zonation. Maximum species diversity is observed in middle Oligocene to early Miocene. Tertiary dinocyst ranges in the Norwegian-Greenland Sea fall within previously known stratigraphic ranges, but, in many cases, are greatly restricted. Some degree of environmental control is suggested. Vertical changes in dinocyst/pollen ratios and palynodebris character indicate "palynoevents" which affect dinocyst assemblages composition and are considered to reflect changes in environment control by geologic processes.
\end{abstract}

\section{INTRODUCTION}

\section{General}

During Leg 38 of the Deep Sea Drilling Project in the Norwegian-Greenland Sea (August-September 1974), Glomar Challenger recovered 1800 meters of postPaleocene sediment from 17 holes. For this report, which should be considered preliminary, dinocysts and their distribution in the Tertiary cores were studied. The aim has been to provide a broad view of a large amount of material from a new area in order to demonstrate the scope and potential guidelines for further studies.

The fossil microflora in this area was essentially unknown until now. Palynological studies have previously been done for the Icelandic Tertiary, but only for sporomorphs in terrestrial sediments (Manum, 1962). Holtedahl et al. (1974) recorded Tertiary pollen from shallow cores from the Norwegian continental shelf, but the nature of the material greatly limits its value for the present study. Palynological studies of Paleogene deposits in Spitsbergen (Manum, 1960, 1962; Vakulenko and Livsic, 1971) were also of limited value, since dinocysts formed only a very minor part. During the last $20 \mathrm{yr}$, there have been numerous studies of dinocysts from onshore Tertiary sediments, particularly of the Paleogene, in Europe and the British Isles. These studies offer the most important source for comparison with the present with regard to taxonomy and stratigraphy. Two recent papers (Williams, 1975; Williams and Brideaux, 1975) on dinocysts from wells and shallow cores from offshore eastern Canada also provide useful data for comparison with the Norwegian-Greenland Sea material.

From what is known of the evolution of the Norwegian-Greenland Sea area since early Tertiary, it can be safely concluded that considerable changes have taken place in the marine environment. Plate-tectonic events have produced changes in distance to shoreline, water depth, and small- and large-scale sea-floor topographic features. Dinoflagellates, like other marine biota, have responded to these and other changes in the environment. An interesting aspect of this study is to see if and how these changes are reflected by dinocysts in the sediments.

Land-derived material (pollen, spores, plant tissue fragments) in relatively near-shore sediments is known to reflect environmental changes. Early in this study, the potential use of a synthetic approach to these palynological remains for environmental interpretations became quite apparent and was developed as part of the study. Extensive analyses were not possible, but some simple observations were made, such as ratios of cysts to pollen (from a thesis by E. Skram Ugland, in preparation) and estimates of amounts and character of tissue fragments in the preparations. Whenever possible, the character and age of reworked material were also noted. The sporomorph component has been studied by other workers and is the subject of another chapter in this volume.

\section{Material}

For this report, material from all holes, except two (Holes 352 and 352A) of Leg 38, was studied. Their locations are shown on Figure 1. More than 400 samples were processed from 277 of a total of 345 cores recovered from these 15 holes. Cores not sampled are, for the most part, either basalt or other paleontologically unproductive lithologies. Sample positions as well as palynomorph productivity for each sample are indicated in the core descriptions for individual sites (see Site Reports, this volume) and are not repeated here.

\section{Preparation of Samples and Quality of Fossils}

Standard processing methods included hot hydrofluoric acid treatment after removal of carbonates, followed by heavy liquid separation $\left(\mathrm{ZnBr}_{2}\right.$, sp. gr. $\left.=2.2\right)$. 

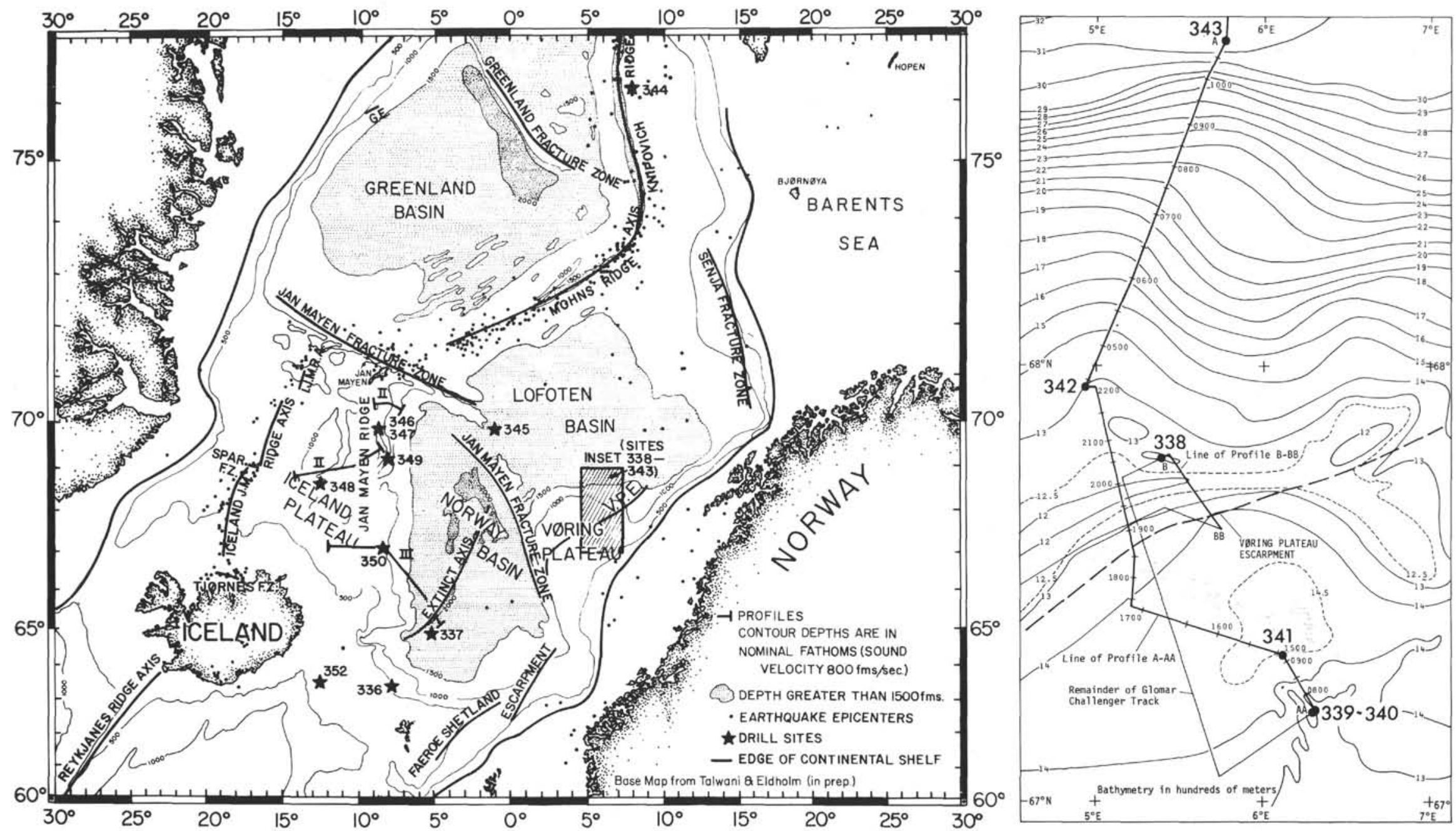

Figure 1. Location of Leg 38 drilling sites, and bathymetry and structure of the Norwegian-Greenland Sea. (Note: Site 351 was occupied but was not drilled. Its location has not been shown on this map.) The inset map shows the track of Glomar Challenger between Sites 338 and 343 on the Voring Plateau. Portion between Sites 339 and 343 corresponds to line of composite profile illustrated in accompanying diagram. Also shown are position of Vhring Plateau Escarpment, and corrected bathymetry of the area, in hundreds of meters, constructed principally from records taken by R/V Vema of Lamont Doherty Geological Observatory, supplemented by Glomar Challenger data. 
Oxidation was never applied. Fine detrital matter adhering to cysts, especially ornamented species, was a problem in many samples. Short-time sonification followed by screening through a $15-\mu \mathrm{m}$ net usually improved results, but many samples remain unsatisfactory even after repeated treatment. However, cysts can still be identified, and preparations may be used for correlation; however, morphological studies and photomicrography are greatly impeded.

The cysts have, in general, suffered little from compaction, and preservation is good to excellent. However, their color is pale and often renders microscopy difficult without staining. Even so, stain was never applied because it might affect recognition of reworked fossils. Processing residues were mounted as strew preparations in glycerol jelly and sealed with paraffin wax under a cover glass.

\section{PALYNOMORPHS AND PALYNODEBRIS: A SYNTHETIC APPROACH}

\section{General}

Studies of the various palynomorphs of terrestrial and marine origins in marine sediments in relation to environment have now reached a fair number (Davey, 1971, with discussion and references to earlier studies; Davey and Rogers, 1975). These studies have demonstrated the complexity in distribution patterns of palynomorphs and have shown that further studies are necessary before models can be developed for safe interpretations of their distribution in ancient sediments. However, the principle that dinocyst/sporomorph ratios increase with increasing distance to shore appears, in general, well established. Early in the present study, great variations in relative abundance of cysts and pollen were observed. Since they were suspected to reflect changes in environmental conditions probably controlled by shoreline displacements, a study of dinocysts/sporomorph ratios appeared to be a natural part of the investigation.

\section{Methods}

In samples containing sufficiently abundant palynomorphs, counts were made of dinocysts (also including doubtful cysts, or acritarchs), bisaccate pollen, and spores plus other pollen. The numbers calculated as percentages of total counts are presented in figures included in the Site Reports for the following sites: 336, 338 (see also Figure 2) through 343, 345, 346, and 348. Other sites gave inadequate results for diagrammatic presentation.

Observations on amounts and character of recognizable terrestrial plant fragments, here termed palynodebris, have also been shown on the figures. Palynodebris is here defined as that component of a palynological preparation residue made up of recognizable fragments of plant cuticles and of wood tissue or tracheidal matter, whether carbonized (mineral charcoal, fusinite particles) or not. Palynodebris is basically water transported, although charcoal particles may be carried by wind into the marine environment from vegetation fire areas. Transport and sedimentation of palynodebris, in general, follow energy patterns of the sedimentary environment.

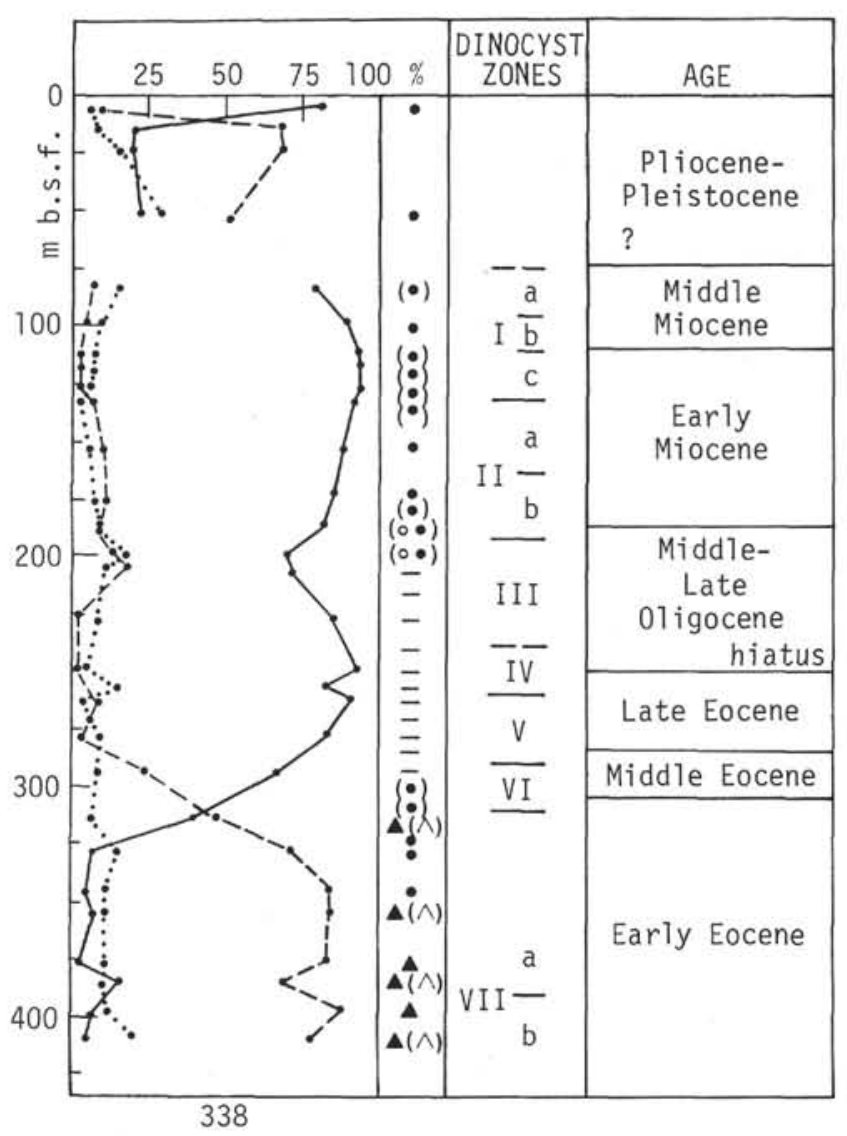

Figure 2. Relative palynomorph abundance and palynodebris composition at Site 338.

Legend:

$$
\begin{aligned}
& \text { - Dinocysts } \\
& - \text { Pollen }+ \text { spores } \\
& \quad \text { excluding saccates } \\
& \text {.. Saccate pollen }
\end{aligned}
$$

Terrestrial plant debris: Mixed cuticular and tracheidal

$\Delta$ altered (dark color)

$\wedge$ unaltered

Sorted, tracheidal mainly

- carbonized (opaque)

- noncarbonized

- No recognizable debris

( ) Debris present but not dominating in prep. residue.

Symbol only: debris dominating

For this study, a rough differentiation into two categories each for type and amount was made of the debris. For type, distinction was made between (1) a diverse debris composition, characterized by the presence of cuticular and tracheidal fragments in varying sizes, and (2) a sorted debris, whose main component is usually tracheidal matter of relatively uniform size, and the absence of the larger size fraction $(>100$ $\mu \mathrm{m})$. For amount, distinction was made between (1) samples whose preparation residues are dominated by debris, and (2) those in which debris is present in varying amounts, but not dominating over palynomorphs. 
Residues with negligible debris were classified along with those without debris.

It was not difficult to assign samples to these broad categories, particularly when the analysis was made successively for a complete sequence of samples from one hole; changes in debris composition were then easily observed. Thermal alteration (carbonization) characteristics of the debris were added as a separate character. For tracheidal matter, altered material is mineral charcoal (fusinite) particles; for cuticles, the alteration was judged by a dark (brown) versus a light (yellow) color. This alteration character was included, since it gives information of the type of debris source when reworking of altered, and usually considerably, older sediments has taken place.

\section{Observations}

A comparison of some deeper holes from which reasonably good and successive data are available reveals some consistent features in relative palynomorph frequencies and palynodebris character. This comparison is best made by first referring to some prominent features in Figure 2 (Site 338).

The curves for dinocysts and for spores plus pollen excluding bisaccates show great and reciprocal variation, whereas the bisaccate curve shows relatively little variation throughout and depicts consistently low values (rarely $>10 \%$ ). These features are well illustrated in figures for other sites (see Site Report chapters for Sites $336,341,343,345,346$, and 348 , this volume), even though the bisaccate curve may sometimes reach slightly higher values (rarely $>20 \%$ ). Only at Sites 336 and 346 does the bisaccate curve show more variations. When the cyst curve depicts values greater than 50\%, the two pollen curves appear nearly parallel at values less than $25 \%$. Samples in which cysts dominate usually contain a few percent of pollen.

Plio-Pleistocene samples contain very variable amounts of palynomorphs, apparently reworked for a very considerable or even major part, and generally the data are inadequate for the construction of curves. Some counts indicate many abrupt changes in relative palynomorph frequencies through the Plio-Pleistocene.

Pre-Pliocene samples having low dinocyst ratios (Site 338 ) are usually dominated by diverse palynodebris. On the other hand, high dinocyst values coincide with absence of debris or with minor amounts of sorted debris (mainly tracheidal and of small size). This relation between debris and dinocyst ratios is a rather consistent feature of pre-Pliocene samples in other sites as well. Only Site 336 shows diverse debris in samples with high dinocyst ratios, however, samples, from this site, with high cyst ratios also contain less debris than those with low cyst ratios.

Plio-Pleistocene samples from all sites studied show considerable variations in amount and character of debris, and they are not obviously correlated with cyst frequencies.

\section{Interpretations}

The observations described above are considered too consistent to be purely accidental. For a possible interpretation of some of these observations, particular attention is given to the noticeable changes in debris amount and usually in character, observed near the points where cyst and pollen curves intersect; that is, when palynomorph assemblages change from pollenrich to cyst-rich, or the reverse. This is present at approximately 320 meters at Site 338 ; at 350 meters at Site 348; from 500 meters to 550 meters, and at 150 meters at Site 345; and at approximately 300 meters at Site 336 (but perhaps somewhat less convincing). Therefore, at these levels, relative palynomorph frequencies and debris character appear independently to reflect changes in the sedimentary environment. These could have been caused by shoreline displacement, by changes in sea circulation patterns, and by major changes in river transport. The shoreline displacement hypothesis is the least difficult to test and will be applied in the following.

At Site 338, sediments from basement upwards to 325 meters are considered to be relatively nearshore. From 325 meters to 290 meters, the shoreline becomes progressively more distant, and from approximately 290 meters upwards to 200 meters, high cyst ratios and absence of debris indicate conditions unaffected by shoreline proximity. To a certain extent, this interpretation finds support in the lithology, which changes from muddy sand to mud with limestone and calcareous oozes at 350 meters (where there is also a change in palynodebris character). Higher in the section the sediments change to mainly biogenic oozes from 275 meters. The data, so far, provide no basis for determinations of actual shoreline distance. These changes took place in early to middle (?) Eocene, during the early phase of opening of the Norwegian Sea.

At 250 meters, the dinocyst curve depicts a downward trend, reversing again at 200 meters, when there is also a change in debris character. These trends are considered to reflect changes in the marine environment. Based on present dating, the change at about 250 meters follows the late Eocene to early Oligocene hiatus at this level at Site 338 . The hiatus probably reflects the early phase of environmental change. The trend at 200 meters occurs in late Oligocene to early Miocene. These major changes in cyst curve trend coincide with marked changes in dinocyst assemblages (Tables 1 and 2). The change at 250 meters is enhanced by the hiatus, but the fact remains that few species range across this level. The changes in dinocyst assemblages are considered to support the idea of reflecting environmental events of a fair magnitude.

Other sites reveal similar changes. In Figure 3, smoothened cyst ratio curves for Sites 336, 338, 343, 345,346 , and 348 are presented. The most conspicuous feature at Sites 345,346 , and 348 is the rise in the curves occurring at about the same time as the rise at Site 338 at 200 meters. Sites 345 and 346, and possibly Site 348, show another prominent feature seemingly correlatable with the late Eocene to middle Oligocene event at 250 meters at Site 338. Since these "palyno-events," which are considered to reflect environmental changes of fair magnitude, appear to be correlatable over wide areas, geological events of a regional nature should be looked for as the cause, probably implying shoreline displacements. Such events are indicated in Figure 3. 
A third major palyno-event, and the first in order of time, is the Eocene change or changes in the cyst curves for Sites 336, 343, 345, and 346, besides Site 338. They are interpreted as marking the initial phase of marine development, affected by relatively nearshore conditions. The occurrence in time of this phase at individual localities depends on their position relative to the area of rifting.

The Plio-Pleistocene has not been considered thus far in the discussion. The samples show little consistency in palynodebris character, great variations may occur abruptly, and quite large palynodebris particles are frequently present. Extensive reworking of older sediments is apparent. Ice-rafting appears to have been the principal transport medium for this material. Site 344 has a Plio-Pleistocene sediment sequence at least 300 meters thick. The palynodebris character contains a component (dominant in the lower parts), which appears markedly more thermally altered than found in other Leg 38 material. Hence, the source for ice-rafted material appears to have been more altered sediments, possibly Spitsbergen. Plant material in Mesozoic and Tertiary sediments in west Spitsbergen shows a remarkably high degree of thermal alteration, decreasing eastward.

\section{Age of Reworked Plant Material}

Reworked material in Tertiary and Pleistocene cores appears to be not older than Cretaceous as judged by identifiable reworked palynomorphs. Notes on age of reworked material are included in individual Site Reports (this volume). The Plio-Pleistocene has inconsistent changes in the age of reworked material, while some degree of consistency is seen in certain prePliocene sequences. Site 346, for instance, has early Tertiary reworked material of relatively poor preservation from total depth to about 125 meters. Between 125 meters and 75 meters, debris is rich in well-preserved cuticles. Their homogeneous appearance suggests little variation in source, and the fossils suggest a Cretaceous age. Above 75 meters, carbonized tracheidal matter dominates, and diverse sources are indicated by Cretaceous and early Tertiary palynomorphs.

\section{DINOCYSTS}

\section{Taxonomy}

Minimum attention in this report is given to taxonomy. The material contains many morphotypes which are identified confidently as known species, and named accordingly. However, more detailed morphological studies are needed for safe differentiation, and identification of many difficult morphotypes. In addition, a number of new species need to be described. For such morphotypes an informal taxonomy is used. Taxonomic aspects of the material will be dealt with in subsequent publications. Purely taxonomic references have not been included in the references, however, readers are referred to Lentin and Williams (1973) which contains the necessary bibliography. No systematic list of species is presented other than that in the distribution chart for Site 338 (Table 1). Arrangement of species in Table 1 is according to archeopyle position.

\section{Dinocyst Distribution Chart, Site 338 (Table 1)}

To provide a basis for a cyst stratigraphy for the area under study, Site 338 was selected for a more detailed study of dinocyst representation, and a distribution chart for this site is presented as Table 1.

The reasons for choosing Site 338 are twofold: (1) shipboard core forms indicated that this site contained the most complete sequence, beginning with early Eocene sediments; (2) cyst assemblages of workable quality were more consistently obtained from Site 338 cores than from any other site.

The chart shows occurrence of dinocyst species in 32 samples fairly evenly distributed from Cores 8 to 42 . Ten additional samples processed from this interval did not yield workable assemblages. Eight samples from the Plio-Pleistocene sequence (Cores 1 to 6 ) were also studied, but this sequence is not included in the chart since it contains rather few cysts and reworked material presents a serious problem in the analysis. The chart merely records presence in a particular sample. Quantitative data for individual species have not been systematically collected at this time.

The chart presents a subjective selection of species. The total number of species present in the material is quite large, estimated at over twice that presented in the chart, and a large number of species (and varieties) observed are undoubtedly new. Main criteria for species selection have been (1) the ease of identification and differentiation, and (2) stratigraphic significance. Undoubtedly, stratigraphically useful species are among those excluded at this stage. Species of Spiniferites and certain allies are examples of a category, which is richly represented in the material, but neglected at this stage for one or both of the reasons stated above.

The ultimate aim is to produce a representative range chart for the whole area, but as yet, other sites have been studied in much less detail, and only the more stratigraphically significant species recorded. Observations from other sites are reported in the individual Site Reports (this volume). A few of these observations indicate extensions of ranges as observed at Site 338 . Also, at Site 338, the Tertiary sequence is incomplete since there appears to be a hiatus between the late Eocene and early Oligocene and the late Miocene may be missing. However, since adequate data for a substantially correct range chart including other sites have not as yet been collected, it is considered best at this point to present distribution for Site 338 without modifications.

\section{A Provisional Zonation}

A selection of species, which appear stratigraphically useful, has been arranged in a stratigraphic order in Table 2, and this has formed the basis for a provisional zonation. Seven cyst zones are distinguished, and for Zones I, II, and VII, further subdivisions are suggested.

The boundary between Zones III and IV is exceptionally clear. There are four significant points concerning this boundary: (1) remarkably few species range across it (compare also Table 1); (2) samples from Cores $25-2$ and 26-2 were nearly unproductive. Ranges 


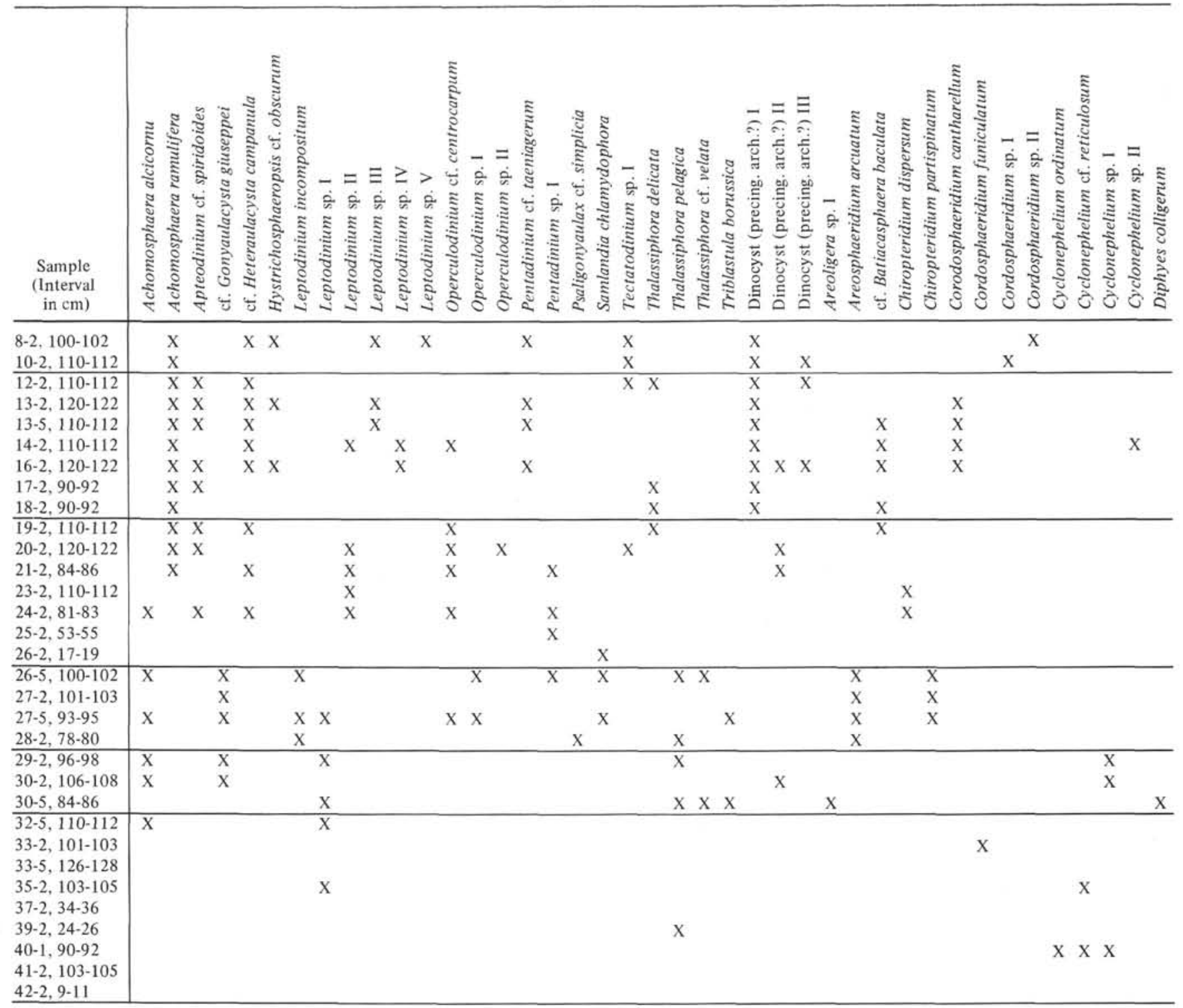

in the lower part of Zone III are, therefore, poorly known; (3) a hiatus is indicated by other fossil groups (particularly diatoms) in the upper part of Core 26 with middle Oligocene sediments. The hiatus obviously affects cyst ranges at this point, and produces a clearer demarcation of the Zone III/IV boundary than would otherwise have been the case. It also makes the application of this zone boundary to other sites doubtful (note, for instance, Sites 336 and 345, see also Site Reports); and (4) the cyst ratios change to a downward trend at the Zone III/IV transition. As discussed in the previous section, this change suggests environmental events more or less coincidental with the hiatus and probably correlatable with corresponding events at other sites (Figure 3).

The Zone II/III boundary is drawn so as to leave a number of species with their first appearances at the top of Zone III (Core 20, Section 2), although it might be more natural to make these first appearances mark the base of Zone II. Some of the species appearing here for the first time do not range higher; examples are three species of Lejeunia. The dinocyst curve reaches a minimum at this point, and also the palynodebris character changes. A likely interpretation of these observations appears to be environmental changes, as discussed previously. The sudden occurrence of Lejeunia spp. should be noted, since it has been suggested that ranges for this genus are environmentally controlled (Williams, 1975, p. 131). More research is needed to shed light on problems indicated here. At this stage, it is preferred to include Core 20, Section 2 in Zone III, giving more emphasis to the first appearances of cf. Batiacasphaera baculata and Thalassiphora delicata in Core 19, Section 2, and the last appearance of Plathycystidia sp. I in Core 20, Section 2. There seems to be maximum species diversity in Zones III to II.

The Zone I/II boundary appears reasonable from cyst ranges known so far, but further analysis of these rich assemblages may well lead to a modified zonation for this Miocene sequence. Certain cyst categories (e.g., Leptodinium) are represented by a series of morphotypes, possibly reflecting evolutionary trends.

The Eocene sequence at Site 338 is in many respects opposite to that for the Miocene. Cyst ratios are lower, particularly in earlier parts, where there is a severe dilu- 
TABLE 1 - Continued

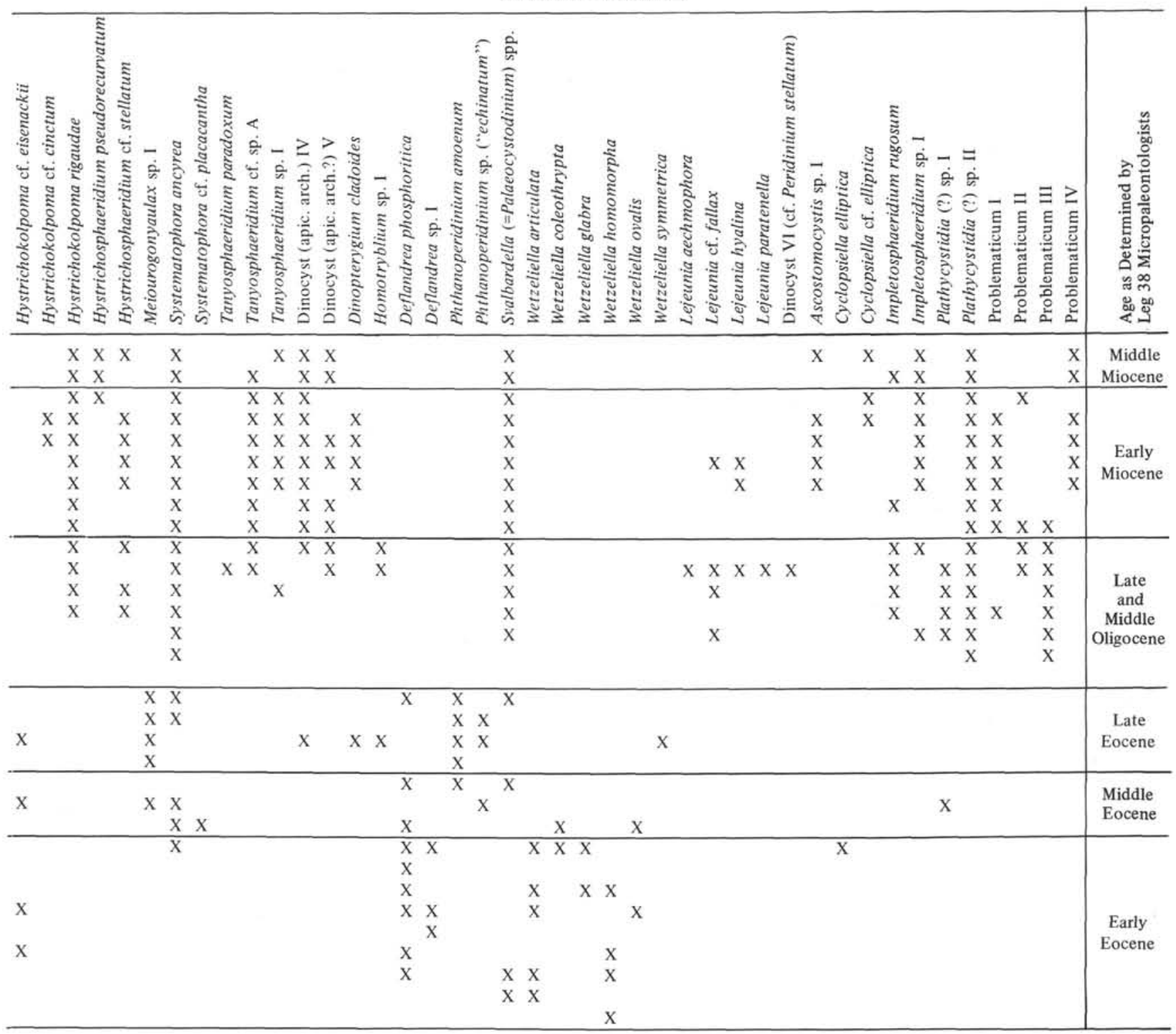

tion effect of sporomorphs and palynodebris. Species diversity appears low, but this may be an artificial dilution effect. Environmental parameters are considered to have significantly controlled cyst-distribution in Core 30 and below; pollen and debris indicate more nearshore environments than at higher levels. Distribution of Cyclonephelium ordinatum and $C$. reticulosum may be examples where ranges of certain cysts appear to be environmentally controlled. At Site 338, they are present in species-poor assemblages in a sequence assigned to Zone VIIa. However, at Site 349 both species, and at Site $336 C$. ordinatum, are present in typical Zone V to VI assemblages. In Zone VIIa at Site 338, and in the sequences at Sites 336 and 349, where they are also present, diverse palynodebris dominates preparation residues, while little or no debris characterizes Zones V and VI at Site 338.

The zonation presented is a first attempt, based on present limited knowledge of Norwegian-Greenland Sea dinocyst distributions. Even so, it has proved fairly workable when applied to material from other sites.

\section{CORRELATION}

Information on dinocyst stratigraphic ranges for the European Tertiary is scattered in several papers dealing with more or less restricted sequences. Among the stratigraphically more important are: Alberti (1961, late Mesozoic and lower Tertiary); Benedek (1972, Oligocene); Gerlach (1961, Oligocene-Miocene); Gocht (1969, lower Tertiary); and Morgenroth (1966, Eocene). A dinocyst zonation for the Tertiary and upper part of the Mesozoic has recently been proposed for the eastern Canadian shelf (Williams, 1975), and the zones are correlated with European stages using dinocyst species whose ranges are similar in Canada and Europe. Stratigraphic range charts, of a more general nature for selected species, are published by the American Association of Stratigraphic Palynologists (Evitt, 1975).

At the present stage of our studies of the NorwegianGreenland Sea material, correlation with known ranges elsewhere cannot be made easily, since relatively few 


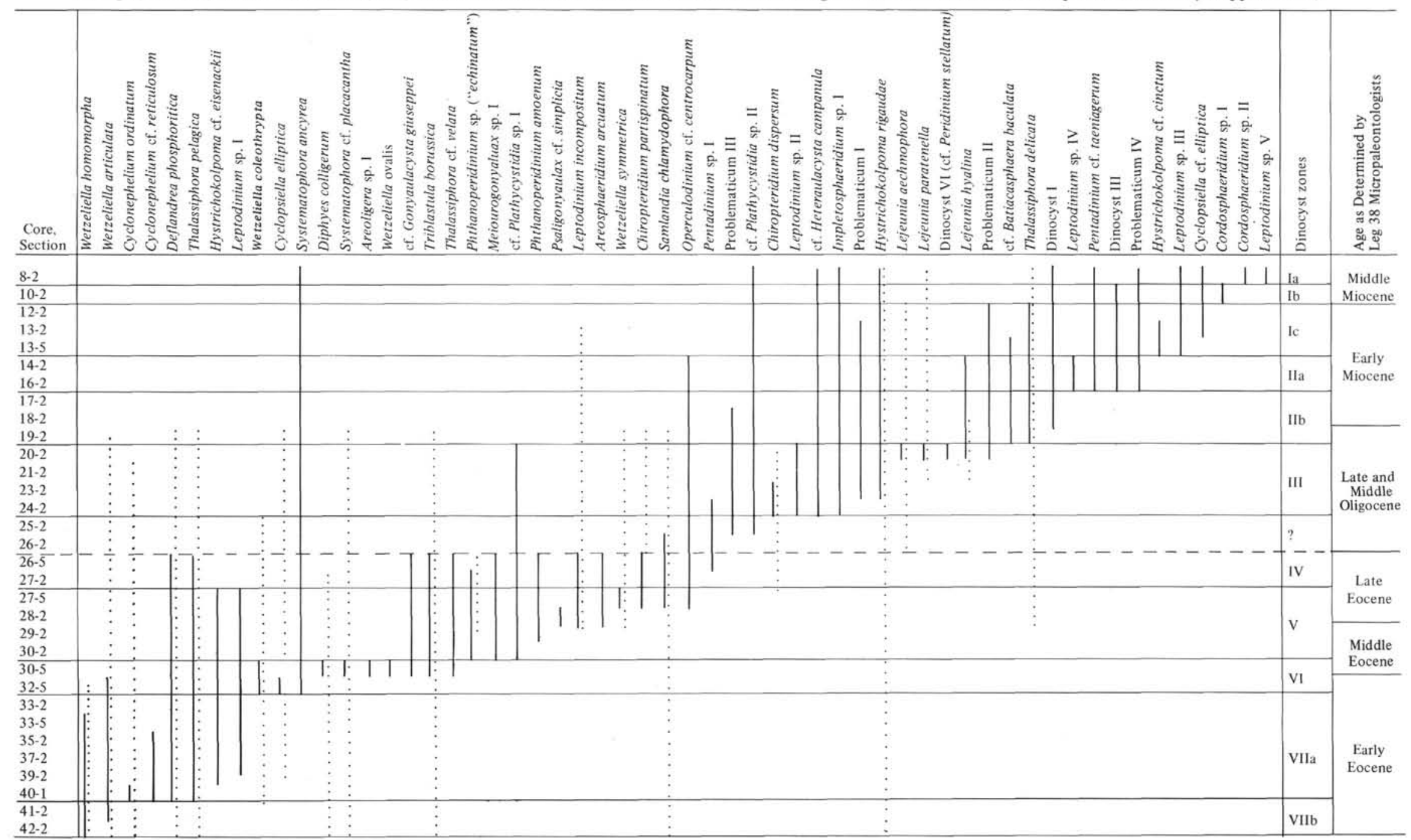




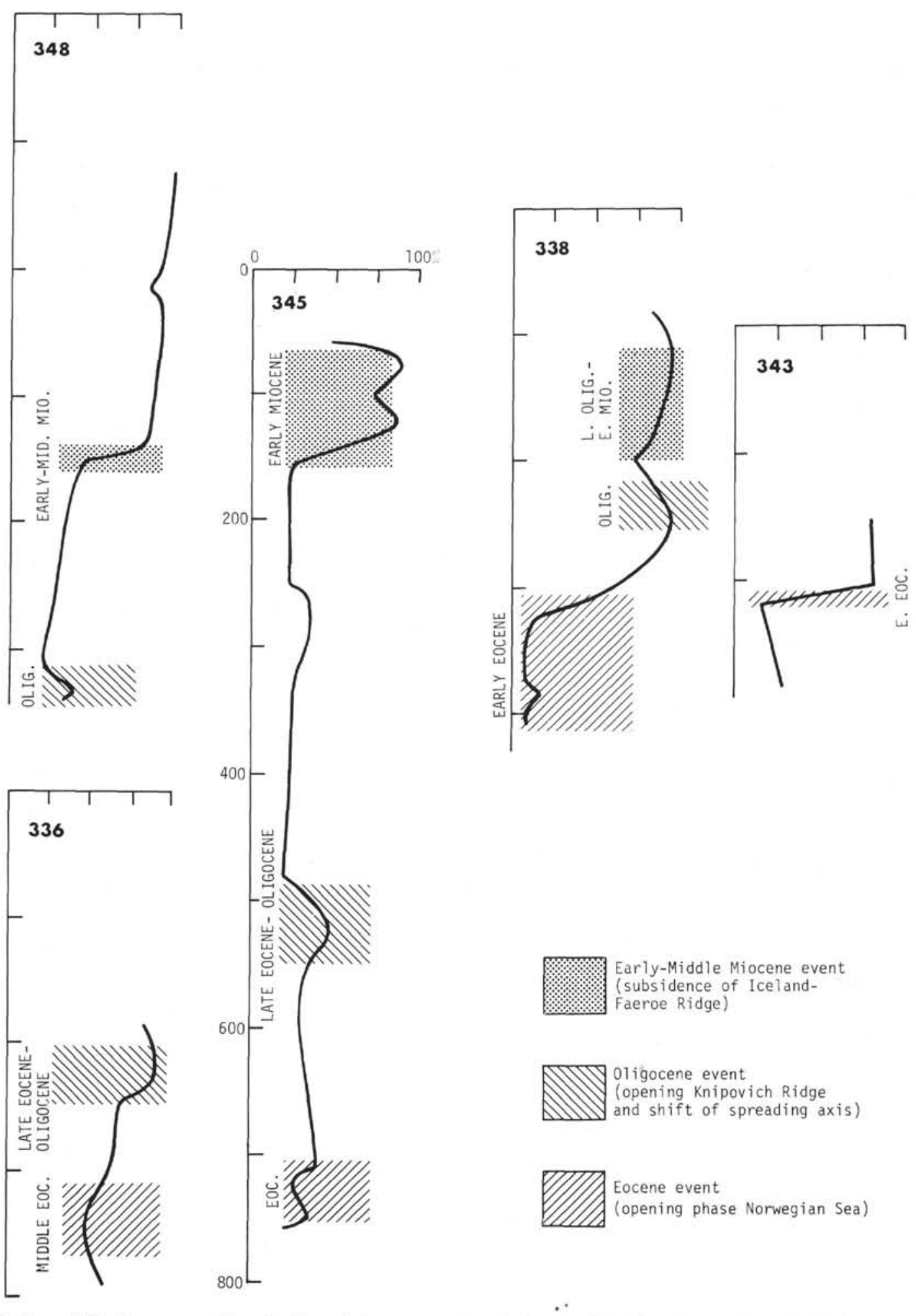

Figure 3. Suggested correlation of "palyno-events" as indicated by cyst ratios for Sites 336, 338, 345, 346, and 348/curves redrawn slightly smoothened from figures presented in Site Report chapter.

species are identified with reasonable confidence to known species. However, some comparisons may be offered.

In Table 2, known ranges for some species are indicated against the ages arrived at by the Leg 38 micropaleontologists. Most of the Site 338 ranges fall well within known ranges, but are narrower.

Wetzeliella homomorpha appears to be common in late Paleocene to early Eocene, and is a diagnostic species of this interval in the eastern Canadian shelf, 
however, it has been recorded also in the late Eocene (Williams, 1975; Williams and Brideaux, 1975). W. articulata and $W$. coleothrypta are diagnostic of early Oligocene assemblages of the Canadian shelf, while they seem to occur a great deal earlier at Site 338. However, their overall ranges are much longer. The more restricted local ranges are probably environmentally controlled, as suggested by their presence in samples from Site 338, with much terrestrial plant material. Cyclonephelium ordinatum and $C$. reticulosum appear to be closely analogous in their distribution. Deflandrea phosphoritica and Thalassiphora pelagica show closely parallel ranges at Site 338 and elsewhere. They have been observed at other sites in late Eocene to early Oligocene strata, which are absent at Site 338. Triblastula borussica in general has a long range. Benedek (1972) recorded it in late Oligocene in Germany, while Williams and Brideaux (1975) reported it to be restricted to late Eocene in the Grand Banks material, closely similar to the range observed at Site 338 . Samlandia chlamydophora is an analogous case. The Phthanoperidinium species belong to the same associations as Triblastula and Samlandia in our material. They appear to be diagnostic of late Eocene to possibly early Oligocene. The genus Chiropteridium appears to be typical of the Oligocene in Germany (Benedek, 1972), and of the middle to late Oligocene from the Canadian shelf (Williams, 1975). In the present material, $C$. partispinatum and $C$. dispersum have, thus far, not been seen in association. $C$. dispersum has a range at Site 338 , similar to that reported from the Canadian shelf, where it is diagnostic of middle to late Oligocene assemblages.

In Grand Banks, Williams and Brideaux (1975) noted a distinct change in dinocyst species composition in what they considered to be late Eocene to early Oligocene. This interval, also, has a marked change at Site 338 , enhanced by the hiatus observed in this interval. A marked decrease in the number of species was observed in post-early Oligocene in the Grand Banks, and particularly in the Miocene-Pliocene. Observations in the Norwegian-Greenland Sea area indicate maximum species diversity in the Oligocene to early Miocene.

Concluding, it would appear that if one were, at this stage, to date on dinocysts alone, one would arrive at ages corresponding to those determined by the combined use of other microfossils, but with less precision.

\section{ACKNOWLEDGMENTS}

Palynomorph ratio diagrams presented in this chapter and in the Site Report chapters were produced by Mrs. Elin Skram Ugland (Department of Geology, University of Oslo) as part of a thesis in preparation, and I wish to thank her for this contribution. Also, I wish to thank Mr. Barrie Dale (Institute of Marine Botany, University of Oslo) for many helpful discussions during the preparation of this paper and for reading parts of the manuscript.

Grants from the Norwegian Research Council for Science and the Humanities and the Royal Norwegian Council for
Scientific and Industrial Research (Continental Shelf Division) towards technical and research assistance are gratefully acknowledged.

\section{REFERENCES}

Alberti, G., 1961. Zur Kenntnis mesozoischer und alttertiärer Dinoflagellaten und Hystrichosphaerideen von Nord- und Mitteldeutschland sowie einigen anderen europäischen Gebieten: Palaeontographica, v. 116A, p. $1-58$

Benedek, P.N., 1972. Phytoplanktonten aus dem Mittel- und Oberoligozän von Tönisberg (Niederrheingebiet): Palaeontographica, v. 137B, p. 1-71.

Davey, R.J., 1971. Palynology and paleo-environmental studies, with special reference to the continental shelf sediments of South Africa. In Farinacci, A. (Ed.), Proc. Plankt. Conf., 2nd, Roma, 1970, Roma (Tecnoscienza), p. 331-347.

Davey, R.J. and Rogers, J., 1975. Palynomorph distribution in Recent offshore sediments along two transects off South West Africa: Marine Geol., v. 18, p. 213-225.

Eaton, G.L., 1969. Dinoflagellate cysts and acritarchs from the Bracklesham Beds of the Isle of Wight. Ph.D. thesis, University of Sheffield.

Evitt, W.R. (Ed.), 1975. Proceedings of a forum on dinoflagellates held at Anaheim, California, October 16, 1973. Am. Assoc. Strat. Palynol., Contrib. Ser. No. 4.

Gerlach, E., 1961. Mikrofossilien aus dem Oligozän und Miozän Nordwestdeutschlands, unter besonderer Berücksichtigung der Hystrichosphaeren und Dinoflagellaten: N. Jb. Geol. Paläont. Abh., v. 112, p. 143228.

Gocht, H., 1969. Formengemeinschaften alttertiären Mikroplanktons aus Bohrproben des Erdölfeldes Meckelfeld bei Hamburg: Palaeontographica, v. 126B, p. 1-100.

Holtedahl, H., Haldorsen, S., and Vigran, J.O., 1974. Two sediment cores from the Norwegian continental shelf between Haltenbanken and Fr $\phi$ yabanken $64^{\circ} 06^{\prime} \mathrm{N}$, $7^{\circ} 39^{\prime} \mathrm{E}$ : Norges Geol. Unders., v. 304, p. 1-20.

Lentin, J.K. and Williams, G.L., 1973. Fossil dinoflagellates: Index to genera and species: Geol. Surv. Canada, Paper 73-42.

Manum, S., 1960. Some dinoflagellates and hystrichosphaerids from the lower Tertiary of Spitsbergen: Nytt Mag. Bot., v. 8, p. 17-26.

1962. Studies in the Tertiary flora of Spitsbergen: Norsk Polarinst. Skr., Nr. 125.

Morgenroth, P., 1966. Mikrofossilien und Konkretionen des Nordwestdeutschen Untereozäns: Palaeontographica, v. 119 B, p. 1-53.

Vakulenko, A.S. and Livšic, Ju. Ja., 1971. Palinologičeskaja charakteristika paleogenovych otloženij Spicbergena; Uč. zap., Paleont. i Biostrat., Nauč., issl. Inst. Geol. Arktiki, v. 31, p. $39-50$.

Wall, D. and Dale, B., 1968. Modern dinoflagellate cysts and evolution of the Peridiniales: Micropaleontology, v. 14, p. 265-304.

Williams, G.L., 1975. Dinoflagellate and spore stratigraphy of the Mesozoic-Cenozoic, offshore eastern Canada: Geol. Surv. Canada, Paper 74-30, v. 2, p. 107-161.

Williams, G.L., and Brideaux, W.W., 1975. Palynological analysis of late Mesozoic-Cenozoic rocks of the Grand Banks of Newfoundland: Geol. Surv. Canada, Bull. 236. 

PLATE 1

(Magnification $\times 500$ )

Figure 1 Achomosphaera alcicornu (Eis.) Davey and Williams, 1966. Sample 339-10-2, 40-42 cm.

Figure 2 Achomosphaera ramulifera (Defl.) Evitt, 1963. Sample 339-10-2, 40-42 cm.

Figures 3-6 Apteodinium cf. spiridoides Benedek, 1972.

3, 4. Sample 338-12-2, 110-112 cm.

5, 6. Sample 338-24-2, $81-83 \mathrm{~cm}$.

Figure 7 cf. Gonyaulacysta giuseppei (Morgenr.) Sarjeant, 1969. Sample 338-27-2, 101-103 cm.

Figure 8 cf. Heteraulacysta campanula Drugg and Loeblich, 1967. Sample 338-8-2, 100-102 cm.

Figures 9-11 Hystrichosphaeropsis cf. obscurum Habib, 1972.

9, 10. Sample $345-6-2,108-110 \mathrm{~cm}$.

11. Sample 338-13-2, $120-122 \mathrm{~cm}$.

Figures 12,13 Leptodinium incompositum (Drugg) Lentin and Williams, 1973.

12. Sample $338-23-2,110-112 \mathrm{~cm}$.

13. Sample $338-26-5,100-102 \mathrm{~cm}$.

Figure 14 Leptodinium sp. II Manum. Sample 338-21-2, 84$86 \mathrm{~cm}$.

Figure 15 Leptodinium sp. III Manum. Sample 338-13-5, $110-112 \mathrm{~cm}$.

Figures 16, 17 Leptodinium sp. I Manum. Sample 338-27-5, 93-95 $\mathrm{cm}$.

Figure 18 Leptodinium sp. IV Manum. Sample 338-19-2, $110-112 \mathrm{~cm}$.

Figures 19, 20 Leptodinium sp. V Manum. Sample 338-8-2, 100$102 \mathrm{~cm}$.

Figure 21 Operculodinium sp. II Manum. Sample 338-20-2, $120-122 \mathrm{~cm}$.

Figure 22 Operculodinium cf. centrocarpum (Defl. and Cooks.) Wall, 1967. Sample 338-26-5, 100-102 cm.

Figures 23, 24 Operculodinium sp. I Manum. Sample 338-26-5, $100-102 \mathrm{~cm}$. 
PLATE 1
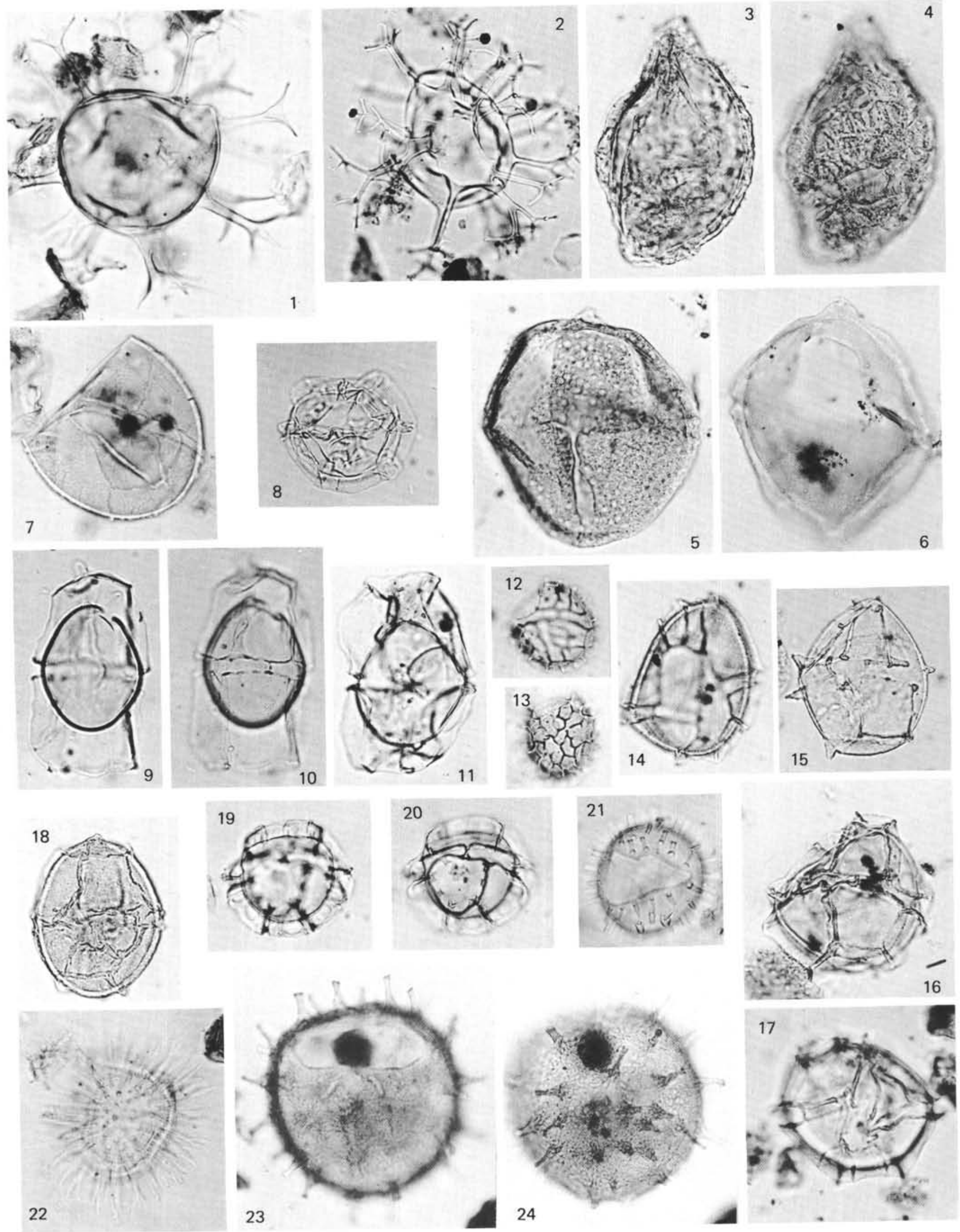


\section{PLATE 2}

(Magnification $\times 500$ unless otherwise stated)

Figures 1, $4 \quad$ Pentadinium cf. taeniagerum Gerlach, 1961.

1. Sample 338-13-2, 120-122 cm.

4. Sample 343-5-2, 70-72 cm.

Figures 2, $3 \quad$ Pentadinium sp. I Manum.

2. Sample 338-24-2, $81-83 \mathrm{~cm}$.

3. Sample $338-26-5,100-102 \mathrm{~cm}$.

Figures 5, 6 Psaligonyaulax cf. simplicia (Cooks. and Eis.) Sarjeant, 1969. Sample 343-5-2, 70-72 cm.

Figures 7,8 Samlandia chlamydophora Eisenack, 1954. Sample $338-26-5,100-102 \mathrm{~cm}$.

Figures 9, 10 Tectatodinium sp. I Manum. Sample 338-13-2, $120-122 \mathrm{~cm}$.

Figure 11 Thalassiphora delicata Williams and Downie, 1966. Sample 338-19-2, 110-112 cm.

Figure 12 Thalassiphora pelagica (Eis.) Eisenack and Gocht, 1960 (×300). Sample 338-26-5, 100-102 cm.

Figure 13 Thalassiphora reticulata Morgenroth, 1966 $(\times 300)$. Sample $336-18-5,56-58 \mathrm{~cm}$.

Figure 14 Thalassiphora $\mathrm{cf}$. velata (Defl. and Cooks.) Eisenack and Gocht, 1960. Sample 338-30-5, 84-86 $\mathrm{cm}$.

Figure 15 Triblastula borussica (Eis.) Morgenroth, 1966. Sample 338-30-5, 84-86 cm.

Figures 16-18 Dinocyst (precingular archeopyle?) I Manum $(\times 1000)$. Sample 338-17-2, 90-92 cm.

Figure 19 Dinocyst (precingular archeopyle?) II Manum $(\times 1000)$, Sample 338-23-2, 110-112 cm.

Figures 20, 21 Dinocyst (precingular archeopyle?) III Manum (×1000). Sample 338-12-2, 110-112 cm.

Figures 22, 23 Areoligera sp. I Manum. Sample 338-30-5, 84-86 $\mathrm{cm}$.

Figure 24 Areosphaeridium arcuatum Eaton, 1971. Sample $338-26-5,100-102 \mathrm{~cm}$.

Figure 25 cf. Batiacasphaera baculata Drugg, 1970. Sample 338-16-2, 120-122 cm. 


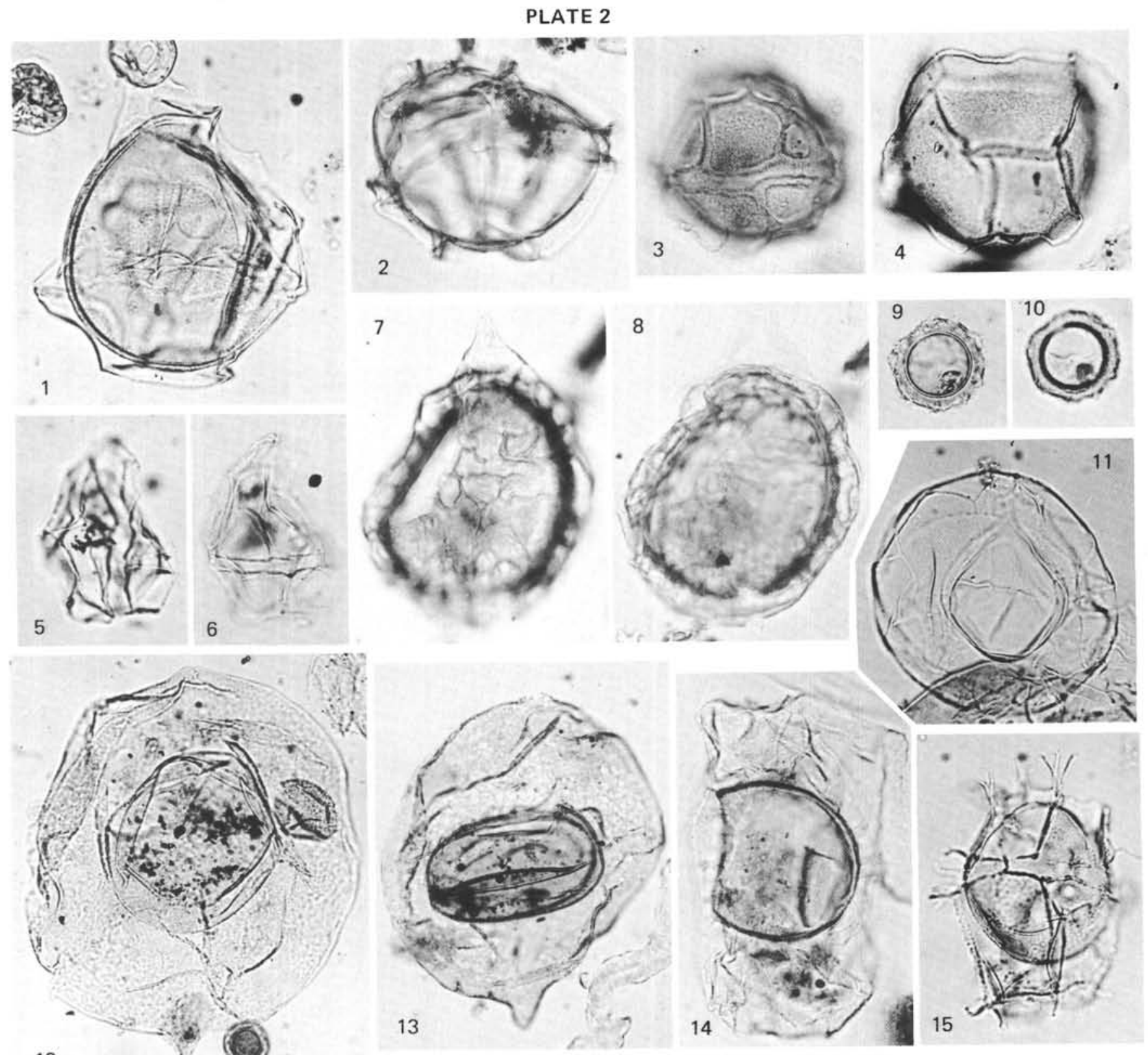

$12 \ldots \pi$ (a)

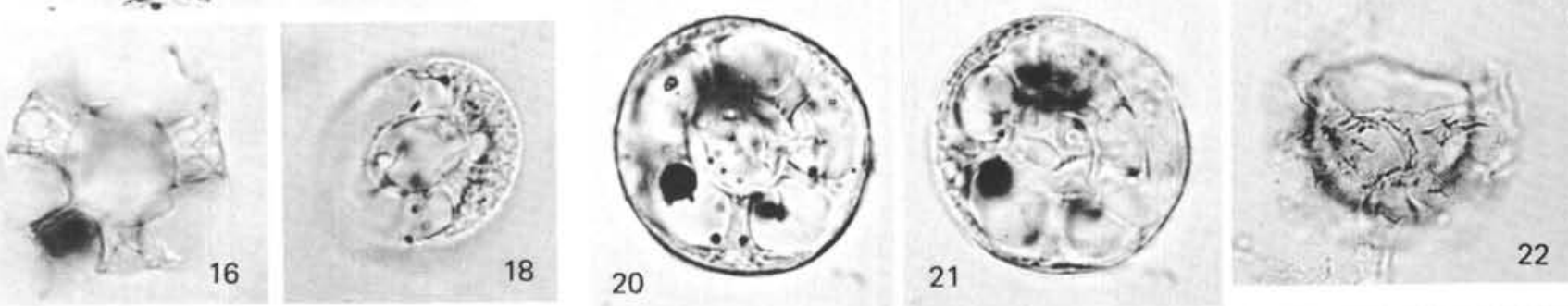




\section{PLATE 3}

(Magnification $\times 500$ unless otherwise stated)

Figure 1 Chiropteridium dispersum Gocht, 1960. Sample $338-24-2,81-83 \mathrm{~cm}$.

Figures 2, 3 Chiropteridium partispinatum (Gerl.) Brosius, 1963. Sample 338-26-5, 100-102 cm.

Figures 4, $5 \quad$ Cordosphaeridium sp. II Manum. Sample 338-8-2, $100-102 \mathrm{~cm}$.

Figure 6 Cordosphaeridium cantharellum (Bros.) Gocht, 1969 (×300). Sample 338-14-2, 110-112 cm.

Figure 7 Cordosphaeridium funiculatum Morgenroth, 1966. Sample 339-5-2, 88-90 cm.

Figure 8 Cordosphaeridium sp. II Manum. Sample 338-102, $110-112 \mathrm{~cm}$.

Figures 9, 10 Cyclonephelium sp. I Manum. Sample 338-21-2, $84-86 \mathrm{~cm}$.

Figure 11 Cyclonephelium ordinatum Williams and Downie, 1966. Sample 338-40-1, 90-92 cm.

Figure 12 Cyclonephelium cf. reticulosum Gerlach, 1961. Sample 338-35-2, 103-105 cm.

Figure 13 Cyclonephelium sp. II Manum. Sample 338-13-2, 120-122 cm.

Figure 14 Cyclonephelium sp. III Manum. Sample 339-10-2, $40-42 \mathrm{~cm}$.

Figure 15 Diphyes colligerum (Defl. and Cooks.) Cookson, 1965. Sample 338-30-5, 84-86 cm.

Figure 16 Hystrichokolpoma rigaudae Deflandre and Cookson, 1955. Sample 338-20-2, 120-122 cm.

Figure 17 Hystrichokolpoma cf. eisenackii Williams and Downie, 1966. Sample 338-18-2, 90-92 cm.

Figure 18 Hystrichokolpoma cf. cinctum Klumpp, 1953. Sample 338-13-2, 120-122 cm.

Figure 19 Hystrichosphaeridium pseudorecurvatum Morgenroth, 1966. Sample 338-12-2, 110-112 cm.

Figures 20,21 Meiourogonyaulax sp. I Manum. Sample 338-27-2, $101-103 \mathrm{~cm}$.

Figure 22 Membranilarnacia ursulae (Morgenr.) de Coninck, 1969. Sample 340-10-2, $110-112 \mathrm{~cm}$.

Figure 23 Systematophora ancyrea Cookson and Eisenack, 1965. Sample 338-13-5, 110-112 cm.

Figures 24,25 Systematophora cf. placacantha (Defl. and Cooks.) Davey et al., 1969. Sample 338-30-5, 84-86 cm. 
PLATE 3
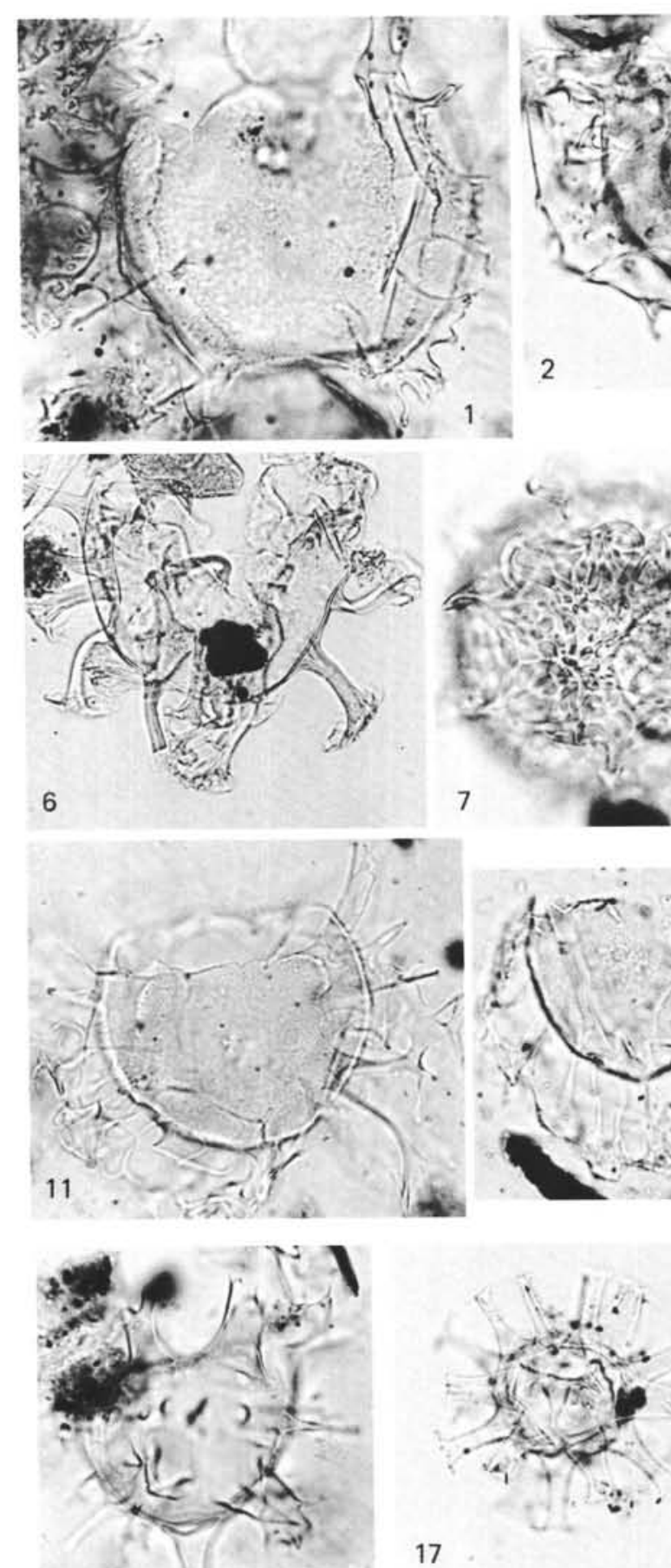

17
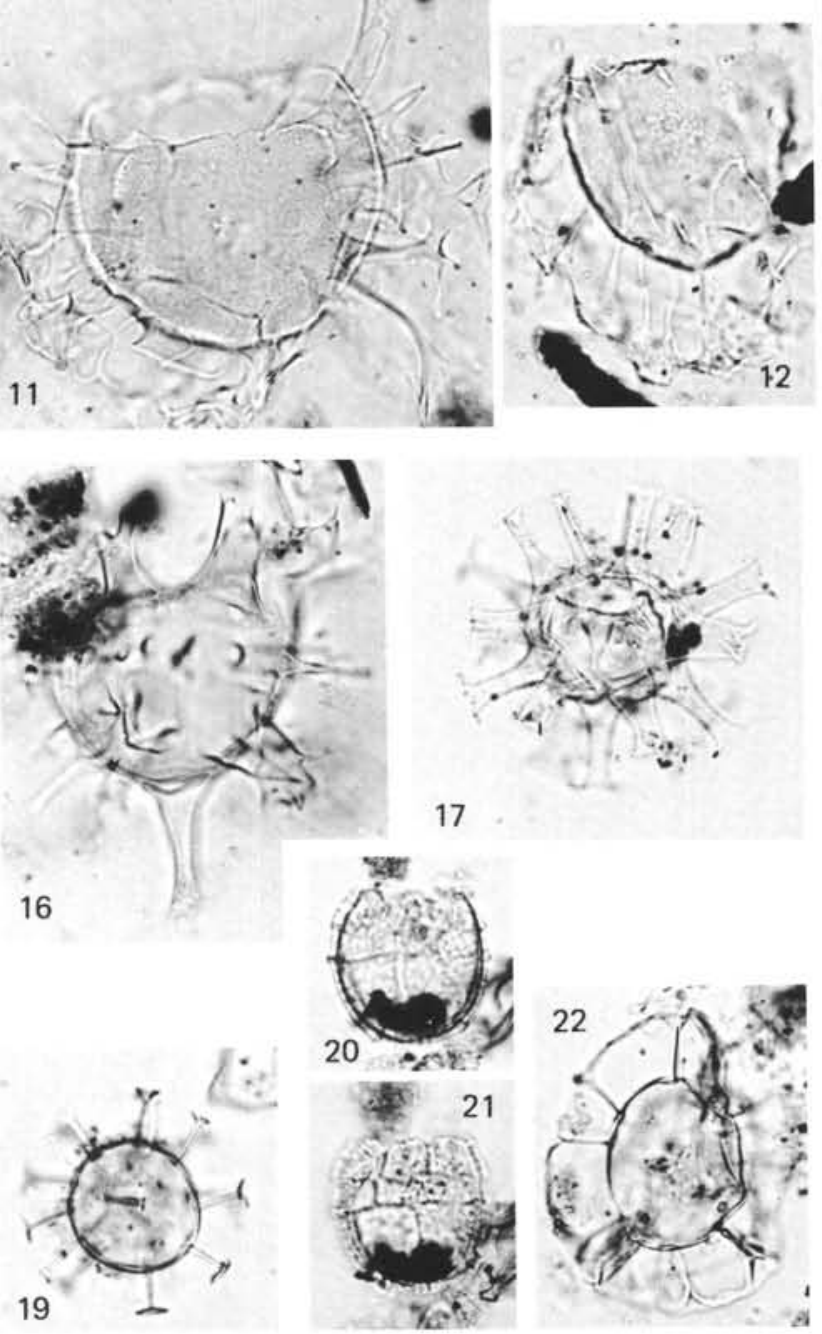

13
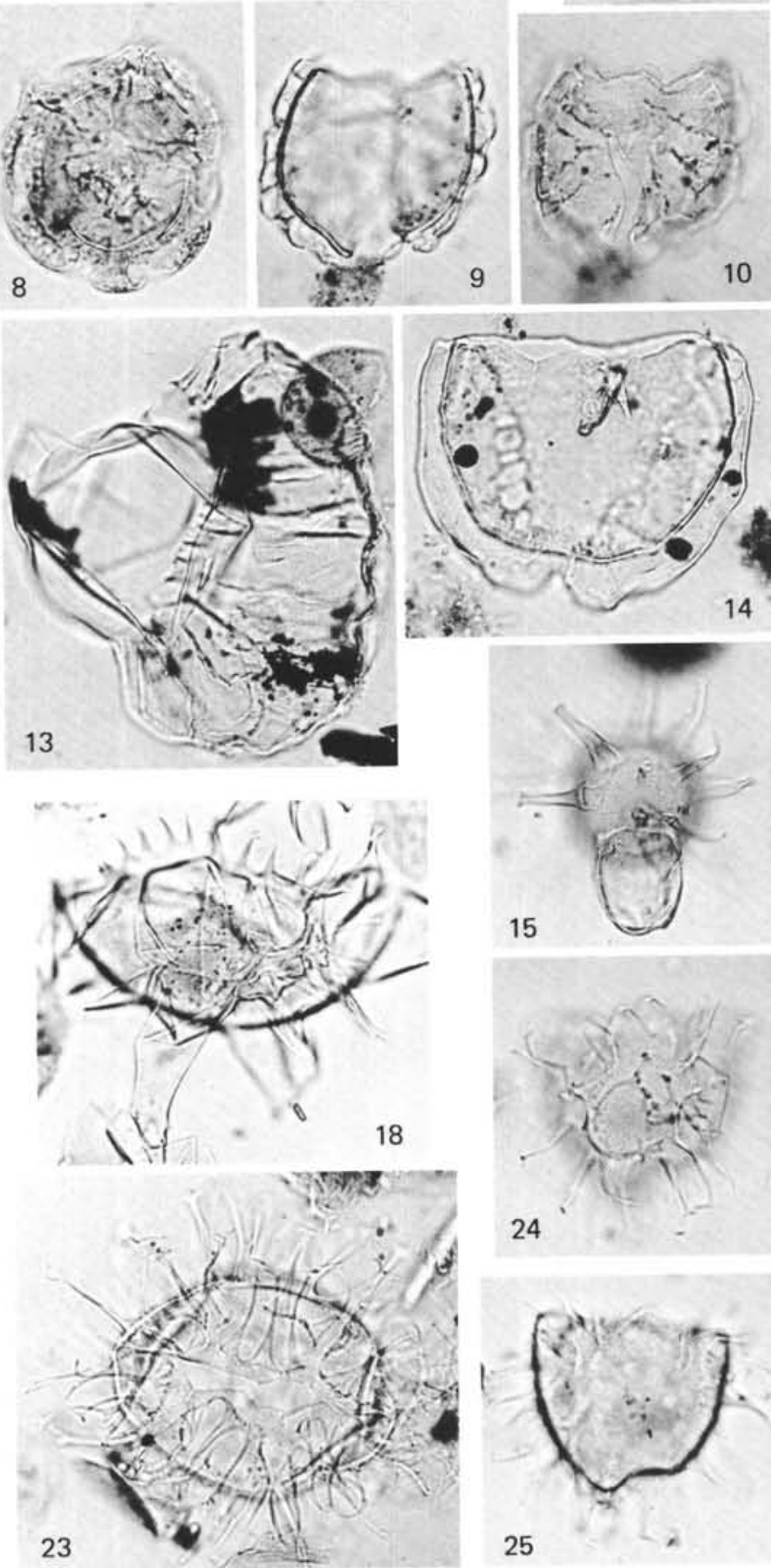

24
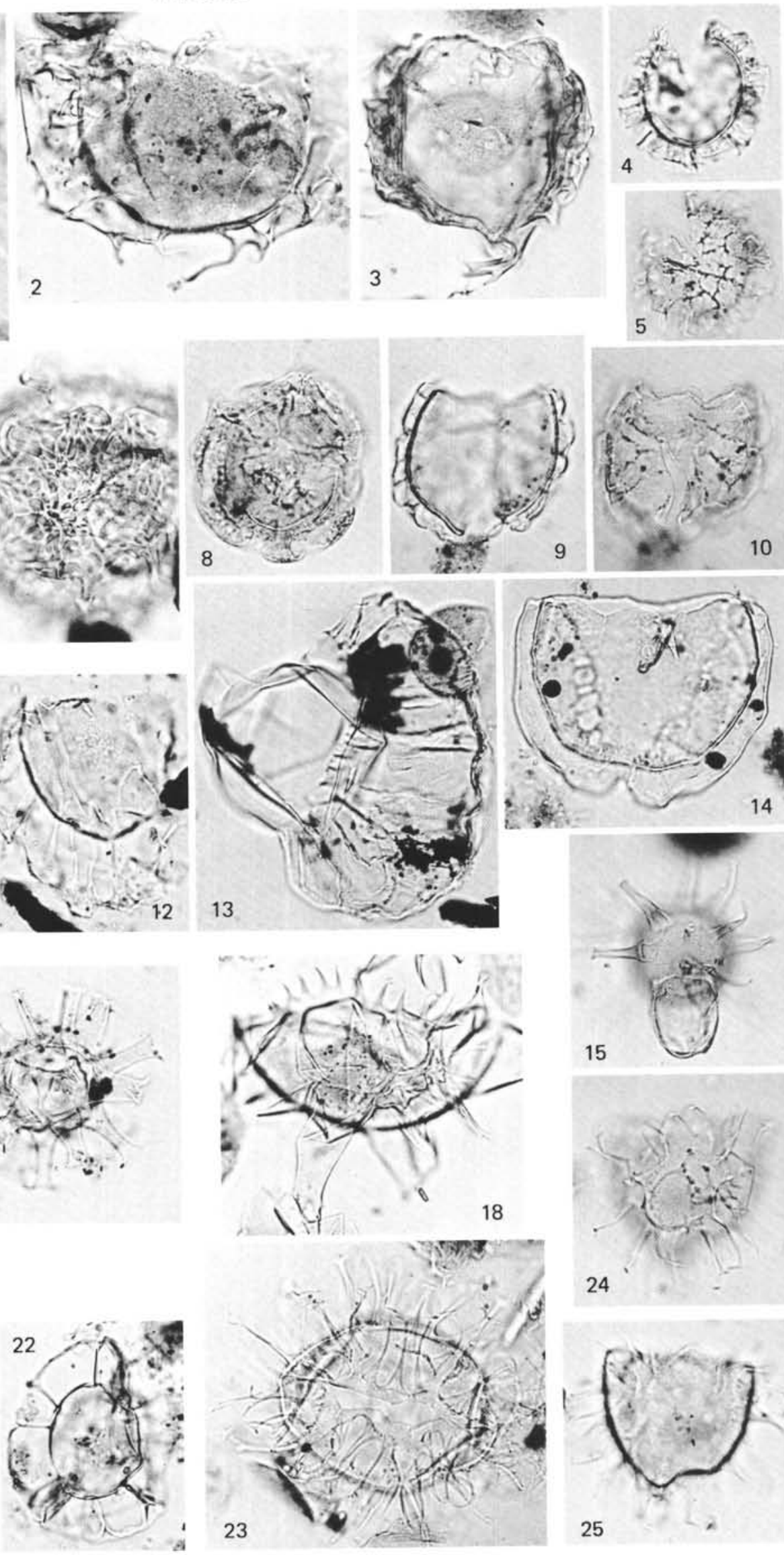


\section{PLATE 4}

(Magnification $\times 500$ unless otherwise stated)

Figure 1 Tanyosphaeridium paradoxum (Bros.) Gocht, 1969, operculum. Sample 338-20-2, 120-122 cm.

Figure 2 Tanyosphaeridium cf. sp. A Williams and Brideaux, 1975. Sample 338-14-2, 110-112 cm.

Figures 3, $4 \quad$ Tanyosphaeridium $\mathrm{sp}$. I Manum.

3. Sample 338-16-2, 120-122 cm.

4. Sample 338-14-2, 110-112 cm.

Figure 5 Dinocyst (apical archeopyle) V Manum. Sample $338-19-2,110-112 \mathrm{~cm}$.

Figures 6,7 Dinocyst (apical archeopyle) IV Manum $(\times 1000)$. Sample 338-17-2, 90-92 cm.

Figures 8, 9 Dinopterygium cladoides Deflandre sensu Morgenroth, 1966. Sample 338-13-5, 110-112 cm.

Figure 10 Homotryblium sp. I Manum. Sample 338-20-2, $120-122 \mathrm{~cm}$.

Figures 11-13 Phthanoperidinium sp. I Manum. Sample 339-10-2, $40-42 \mathrm{~cm}$.

Figures 14-16 Phthanoperidinium amoenum Drugg and Loeblich, 1967 ( $\times 1000)$. Sample 338-27-5, 93-95 cm.

Figures 17, 18 Phthanoperidinium sp. ("echinatum" Eaton, 1969) (×1000). Sample 338-30-2, 106-108 cm.

Figures 19, 20 Phthanoperidinium resistente (Morgenr.) Eisenack and Kjellström, 1971. Sample 339-12-2, 120-122 $\mathrm{cm}$.

Figure 21 Deflandrea sp. I Manum. Sample 339-10-2, 40-42 $\mathrm{cm}$.

Figure 22 Deflandrea phosphoritica Eisenack, $1954(\times 300)$. Sample 338-33-5, 126-128 cm. 
PLATE 4

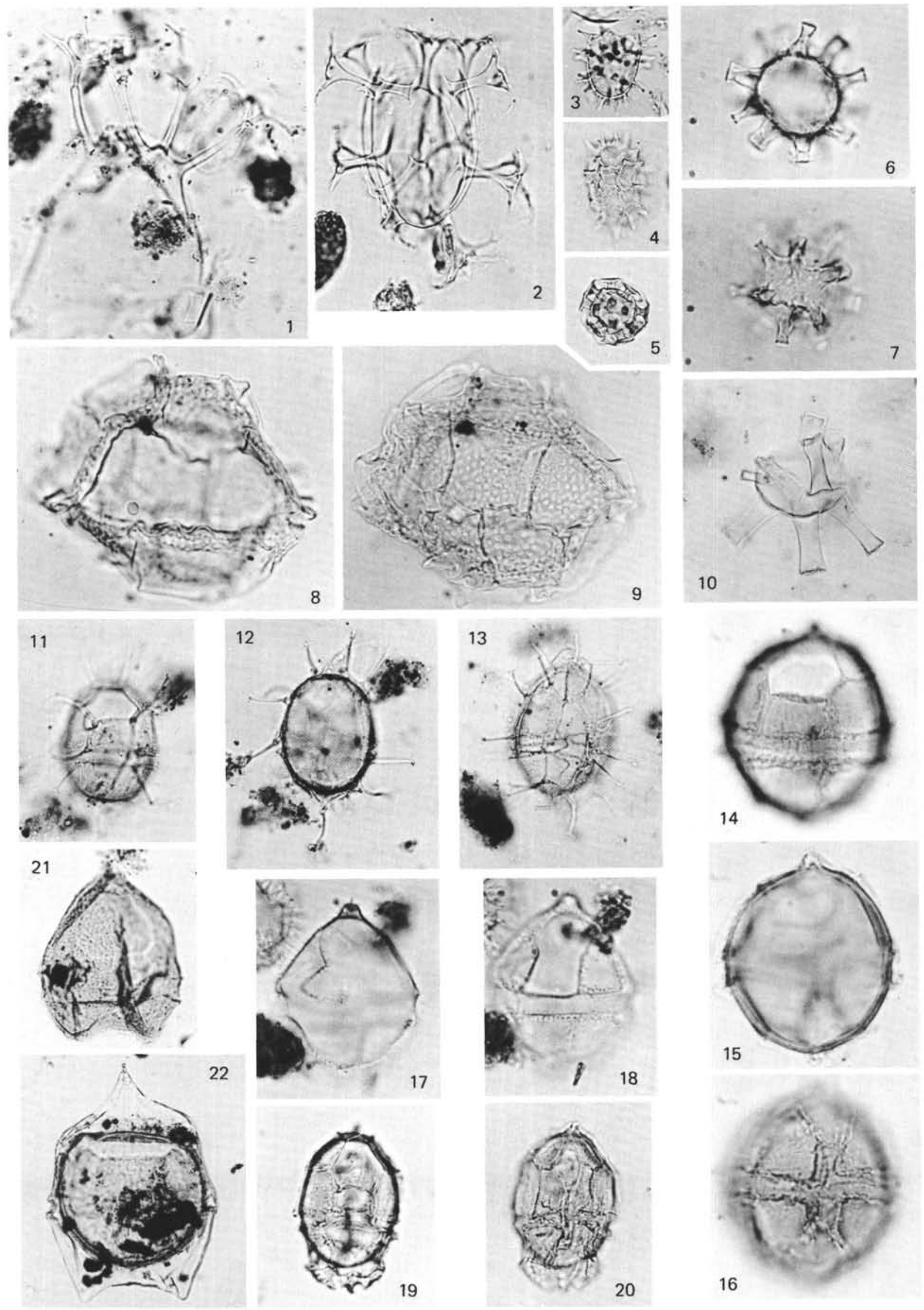




\section{PLATE 5}

(Magnficiation $\times 500$ unless otherwise stated)

Figures 1, 2 Svalbardella (Palaeocystodinium) spp.

1. Sample 338-26-5, 100-102 cm.

2. Sample 338-16-2, $120-122 \mathrm{~cm}$.

Figure 3 Wetzeliella articulata Eisenack, 1938. Sample 338$33-5,126-128 \mathrm{~cm}$.

Figure $4 \quad$ Wetzeliella ovalis Eisenack, 1954. Sample 338-30$5,84-86 \mathrm{~cm}$

Figure $5 \quad$ Wetzeliella glabra Cookson, $1956(\times 300)$. Sample $338-32-5,110-112 \mathrm{~cm}$.

Figure $6 \quad$ Wetzeliella symmetrica, Weiler, 1956. Sample 338$27-5,93-95 \mathrm{~cm}$.

Figure 7 Wetzeliella coleothrypta Williams and Downie, 1966 (×300). Sample 340-1-2, 131-133 cm.

Figure $8 \quad$ Wetzeliella homomorpha Deflandre and Cookson emend. Williams and Downie, 1966. Sample 338$33-5,126-128 \mathrm{~cm}$.

Figure 9 Lejeunia cf. fallax Morgenroth, 1966. Sample 338$24-2,81-83 \mathrm{~cm}$.

Figure 10 Lejeunia hyalina Gerlach, 1961. Sample 338-20-2, $120-122 \mathrm{~cm}$.

Figure $11 \quad$ Lejeunia aechmophora Benedek, 1972. Sample 33820-2, $120-122 \mathrm{~cm}$.

Figures 12,13 Lejeunia paratenella Benedek, 1972. Sample 338$26-2,17-19 \mathrm{~cm}$.

Figures 14-16 Dinocyst VI (cf. Peridinium stellatum Wall in Wall and Dale, 1968). Sample 338-20-2, 120-122 cm. 
PLATE 5

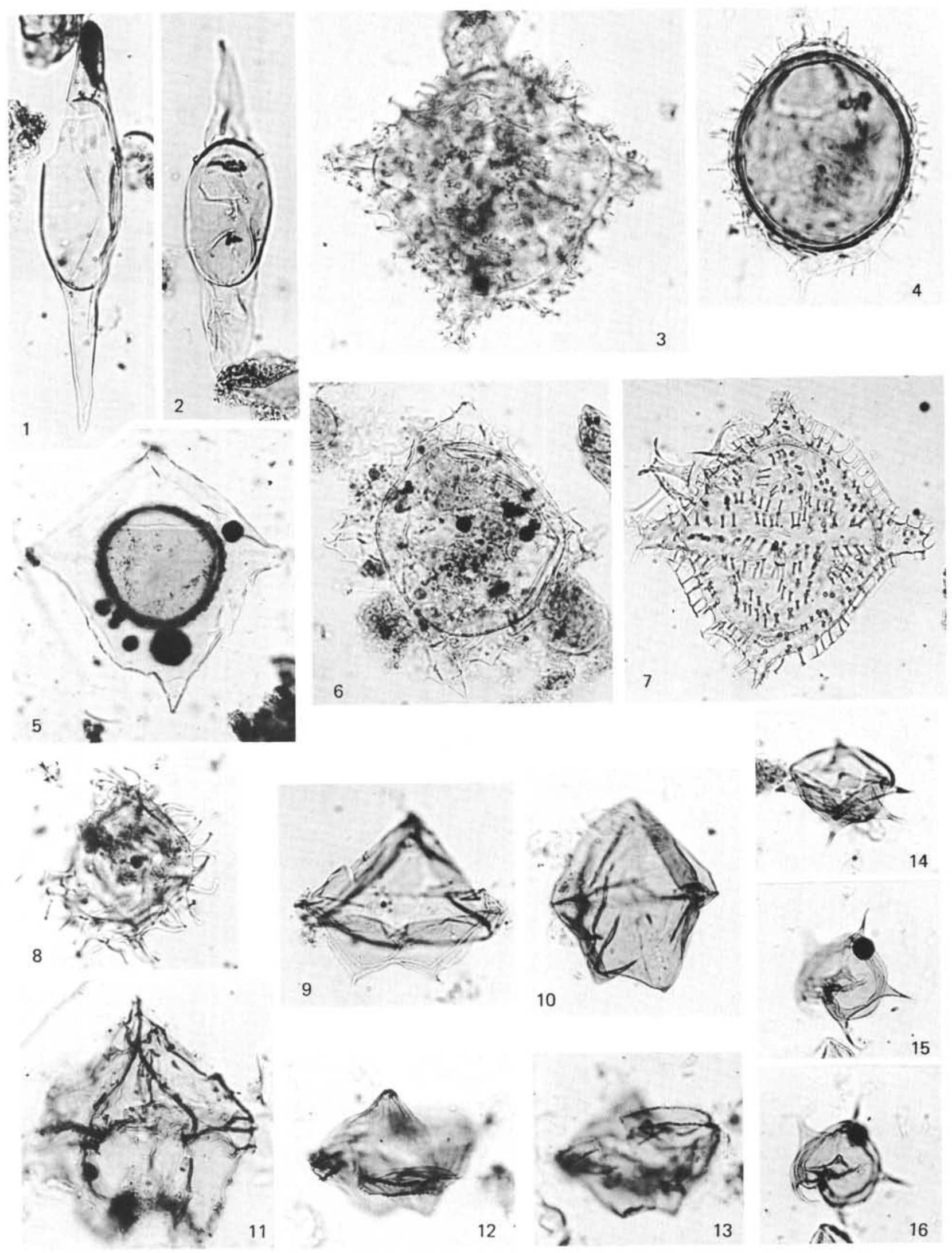




\section{PLATE 6}

(Magnification $\times 500$ unlsss otherwise stated)

Figures 1,2, 5 Ascostomocystis sp. I Manum. Sample 338-13-5, $110-112 \mathrm{~cm}$.

Figure 3 Cyclopsiella elliptica Drugg and Loeblich, 1967. Sample 338-32-5, 110-112 cm.

Figure 4 Cyclopsiella cf. elliptica. Sample 338-13-2, 120-122 $\mathrm{cm}$.

Figures 6,7 Impletosphaeridium rugosum Morgenroth, 1966. Sample 338-21-2, 84-86 cm.

Figures 8,9 Impletosphaeridium sp. I Manum (Figure 9 $\times 1000$ ). Sample 338-13-2, $120-122 \mathrm{~cm}$.

Figures 10-16 Plathycystidia (?) sp. I Manum $(\times 1000)$. 10, 11. Sample 338-21-2, $84-86 \mathrm{~cm}$. 12-16. Sample $338-32-2,110-112 \mathrm{~cm}$.

Figures 17-22 Plathycystidia (?) sp. II Manum $(\times 1000)$.

17. Sample 338-13-5, $110-112 \mathrm{~cm}$. 18-22. Sample $338-21-2,84-86 \mathrm{~cm}$.

Figure 23 Problematicum IV Manum $(\times 1000)$. Sample 338$13-5,110-112 \mathrm{~cm}$.

Figures 24, 25 Problematicum II Manum. Sample 338-20-2, 120 $122 \mathrm{~cm}$.

Figures 26-30 Problematicum III Manum $(\times 1000)$. 26-28. Sample 338-24-2, $81-83 \mathrm{~cm}$. 29 , 30. Sample $338-23-2,110-112 \mathrm{~cm}$.

Figure 31 Problematicum I Manum. Sample 338-13-2, 120$122 \mathrm{~cm}$. 
PLATE 6
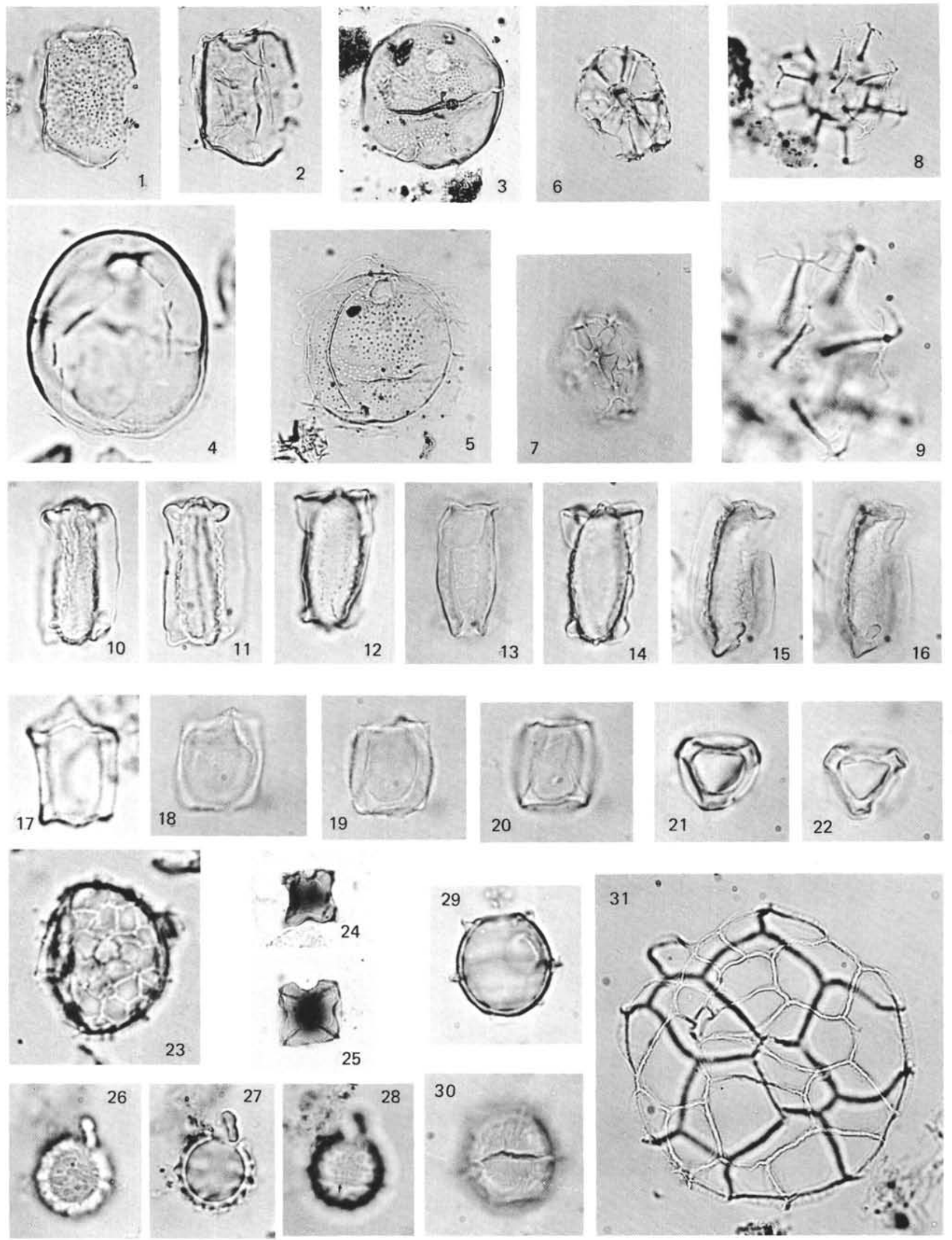